Egyptian Poultry Science Journal

http://www.epsj.journals.ekb.eg/

ISSN: 1110-5623 (Print) - 2090-0570 (Online)

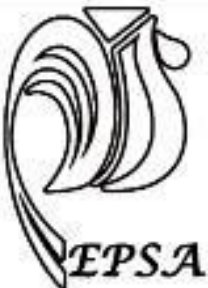

\title{
SUPPLEMENTAL THREONINE SUPPORTS PRODUCTIVE AND PHYSIOLOGICAL STATUS OF JAPANESE QUAIL FED PROTEIN- RESTRICTED DIETS
}

\author{
S.A. Abdel-Fattah ${ }^{1}$, A.A. Khattab ${ }^{2}$ and M.A.M. Abdelaziz ${ }^{1}$ \\ ${ }^{1}$ Poult. Prod. Dept., Fac. of Agric., Ain Shams University \\ ${ }^{2}$ Anim. Prod. Dept., Fac. of Agric., Tanta University
}

Corresponding author: Mrwan Abdelaziz; E-mail: mrwanabdelaziz@agr.asu.edu.eg

Received: 08/09/2020

Accepted: $23 / 09 / 2020$

\begin{abstract}
Six-weeks experimental trial was conducted to evaluate the effects of excess dietary threonine [Thr] (150\% and $200 \%$ of NRC recommendations) with levels of $21 \%$ and $22 \%$ dietary protein on productive performance, blood biochemical parameters and small intestine histological structure of Japanese quail. Three hundred and fifteen one-day-old unsexed Japanese quail chicks were randomly assigned for seven experimental groups, 45 chicks each. T1- chicks were fed the basal (control) diet contained $24 \%$ crude protein; T2 and T3-birds were fed diets contained normal requirement of [Thr] with 22 and $21 \%$ crude protein, respectively; T4 and T5-quails received $22 \%$ crude protein with $150 \%$ or $200 \%$ [Thr], respectively; T6 and T7-were given $21 \%$ crude protein with $150 \%$ or $200 \%$ [Thr], respectively. The obtained results showed that [Thr] supplementations particularly $150 \%$, improves quail productive performance and compensates dietary protein restriction. Plasma concentrations of total protein, albumin, high-density lipoprotein (HDL), and glucose were increased significantly $(\mathrm{P}<0.01)$, while triglycerides and low-density lipoprotein $(\mathrm{LDL})$ were decreased with [Thr] dietary addition. Kidney and liver functions were not negatively influenced with [Thr] supplementation at any level. The histological observations of intestine showed greater villi height and higher goblet cells number with [Thr] supplementation indicating better digestibility and utilization of feed nutrients. It could be concluded that, supplementary [Thr] at $150 \%$ of basal requirement of broiler quails was sufficient to compensate for reduction of dietary crude protein below the NRC recommendations, the therefore, [Thr] supplement had no adverse effect on kidneys and liver functions and improved intestinal status, structure and functions.
\end{abstract}

Key words: threonine; quail; protein; performance; blood; histology 


\section{INTRODUCTION}

Poultry farming as one of the vital beneficial sectors of human activity plays an increasing role in bridging the gap between production and consumption by providing considerable quantities of protein, fatty acids, minerals, and vitamins with excellent qualities (FAO, 2013). To increase the benefit of poultry investments from the view of nutrition, feed expenses reduction presents a great challenge, especially with protein costs. Recently, there is eminent interest in the usage of alternative cheap protein sources and/ or maximizing utilization of low dietary protein levels in animal feeds (Olukomaiya et al., 2019). Generally, quail performance can be improved by providing a balanced diet along with some supplements (VargasSánchez et al., 2019).

Dietary supplements represent a significant tool in modulating performance, immunity, and production of animals, in terms of quality and quantity (Aksu et al., 2011; Britanico et al., 2012; Fathi et al., 2016; ElSenousey et al., 2018). Threonine (2-amino3-hydroxy butanoic acid) is an essential amino acid, which plays a role in several biological processes of livestock animals (Ayasan, 2004; Kidd et al., 1999), as it is an essential component of intestinal mucin and plasma g-globulin (Kim et al., 2007; Schaart et al., 2005). Great portions of threonine (Thr) are utilized in the small intestine, suggesting that $\mathrm{Thr}$ is involved in intestinal functionality and maintenance (Van der Schoor et al., 2002). Threonine is vital in protein synthesis, stimulating cell growth, cellular signaling mechanisms, and promotes antibody production (Duval et al., 1991; Li et al., 1999). Besides, it is believed that Thr supplementation boosts feed intake and body weight (Estalkhzir et al., 2013; Khan et al., 2006).

Few studies have been conducted on quail to evaluate possible influences of dietary $\mathrm{Thr}$ supplements with low dietary protein, and controversial results have been reported (Abbasi et al., 2014). Thus, this study aimed to investigate effects of extra dietary Thr supplementations $(150 \%$ and $200 \%$ of NRC requirement for quails) in combination with low dietary protein $(22 \%$ and $21 \% \mathrm{CP})$, on growth performance, blood biochemical parameters and intestinal histological status of Japanese quail.

\section{MATERIALS AND METHODS}

\section{Animals and experimental design}

The present study was carried out at the experimental quail farm, Poultry Production Department, Faculty of Agriculture, Ain Shams University. Three hundred and fifteen unsexed one-day old chicks with initial live weight of $9.01 \pm 0.15 \mathrm{~g}$, were randomly distributed to seven experimental groups, with 45 chicks in each group. Chicks of T1 were fed the basal diet (control), which contained 24\% CP; T2 and T3 were fed diets contained $22 \%$ and $21 \% \mathrm{CP}$, respectively; $\mathrm{T} 4$ and $\mathrm{T} 5$ received $150 \%$ Thr with $21 \%$ and $22 \% \mathrm{CP}$, respectively; T6 and T7 were given $200 \%$ Thr with $21 \%$ and $22 \%$ CP, respectively. Chicks were raised for 6 weeks in an open house system and were offered both feed and clean drinking water $a d$ libitum. The formulation and proximate composition of the experimental diets were shown in Table 1. During the experimental period, body weight (BW, g) was recorded individually, and weight gain (BWG, g) was calculated weekly to the nearest $0.1 \mathrm{~g}$. Feed intake (FI, g) was calculated by subtracting the amount of feed left from that supplied. Feed conversion ratio (FCR) was calculated as the number of grams of feed required to produce one gram of body weight during the same period.

\section{Samples collection and analytical procedure}

Chemical analyses of experimental diets, were performed using standard methods (AOAC, 2010) for dry matter by dehumidification by drying till constant weight at $110{ }^{\circ} \mathrm{C}$, crude protein content by applying the method of Kjeldahl, crude lipid by Soxhlet solvent extraction method and ash by burning samples in Muffle furnace 
for $4 \mathrm{hr}$ at $550{ }^{\circ} \mathrm{C}$. Amino acid contents of diets, were measured using HPLC (Wincom Co. ltd). At the end of the feeding trial, chicks were fasted for $12 \mathrm{~h}$ prior to final sampling. Five quails from each group were randomly selected and slaughtered. Blood samples were collected from each bird in a heparinized $10 \mathrm{ml}$ centrifuge tubes (heparin $20 \mathrm{IU} / \mathrm{ml}$ ), and then plasma was obtained by centrifugation at $3000 \mathrm{rpm}$ for $15 \mathrm{~min}$ under $4^{\circ} \mathrm{C}$. All plasma parameters were determined using commercial kits (Transasia BioMedicals, India). Plasma total protein and albumin were determined using colorimetric method according to Gornall et al. (1949) and Doumas et al. (1971) and globulin was then calculated by subtracting albumin value from corresponding total protein value for the same sample. Triglycerides and cholesterol concentration were determined according to recommended method of Richmond (1973). Aspartic amino transfers (AST) and alanine amino transfers (ALT) were detected according to Reitman and Frankel (1957). Determination of cholesterol, HDL, and LDL were performed according to Watson (1960), Herrmann et al. (1983), and Okada and Ishida (2001), respectively. While uric acid was determined according to method described by Caraway (1955). And glucose levels were also determined as described by Trinder (1969).

Histology samples of small intestine were collected after decapitation. According to the standard histological process, samples were fixed in Bouin's solution for 24 hours, then dehydrated in elevated concentrations of alcohol, equilibrated in xylene, embedded in paraffin, and were cut to sections of 5-7 $\mu \mathrm{m}$ thick. Sections were stained with haematoxylin and eosin according to the methods described by Bancroft and Stevens (1990) and then subjected for examination by light microscopy.

\section{Statistical analysis}

All data were analyzed by one-way analysis of variance (ANOVA) followed by Duncan's multiple range tests (Duncan, 1955) to compare the means between individual treatments using statistical analysis system (SAS, 2004) version 9.1 for Windows at $\mathrm{P}<0.01$ level, and presented as means with \pm standard error of mean (S.E.M, r=3). Data were subjected to statistical analysis according to the following model: $Y_{i j}=\mu+T_{i}+e_{i j}$ Where; $\mathrm{Y}_{\mathrm{ij}}=$ the experimental observation, $\mu=$ overall mean, $\mathrm{T}_{\mathrm{i}}=$ dietary treatment, $\mathrm{e}_{\mathrm{ij}}=$ experimental error.

\section{RESULTS AND DISCUSSION}

Table 2 shows the effect of different dietary protein and Thr levels on the productive performance of Japanese quail. It is clear that, feeding quail chicks on diet contained $3 \%$ lesser protein (T3) than the NRC (1994) recommendation ( $24 \%$ protein) reduced the final body weight significantly when compared with those whose diets contained the same protein level in combination with $150 \%$ Thr addition of the optimal requirement (T6) and those fed on control diet. While the remaining treatments (T2, T4, T5 and T7) had intermediate values. Similar trend was typically found for the results of body weight gain. The highest and the lowest feed intake were recorded for the chicks fed on control (T1) and $22 \%$ protein plus $150 \%$ Thr (T4), respectively. Moreover, T6 group had significantly $(\mathrm{P}<0.05)$ recorded the best FCR followed by $\mathrm{T} 7$ and T4 groups, while the worst FCR was obtained for T3. These findings pointed out that, supporting low protein quail diets with amino acid Thr at either 150 or $200 \%$ of the optimal level is enough to compensate for the dietary protein restriction, particularly $150 \%$. Thereby, based on our finding herein, there is no need for increasing the Thr level above $150 \%$ of the optimal requirements. Moreover, quail broilers have the ability of maintaining body weight and weight gain at constant rate when fed on diet contained $22 \%$ protein (T2) as established with the absence of significance when compared with that of control chicks (T1).

The present results are coincided with those of Estalkhzir et al. (2013) and Rezaeipour et al. (2015) who found that dietary Thr supplementation improved productive performance of broiler chicken in terms of 
BW, BWG and FCR. In addition, Chen et al. (2017) reported that feeding broiler chicks on diet containing $0.81 \% \mathrm{Thr}$ led to a $5.1 \%$ better FCR than chicks given NRC recommended Thr (0.74\%). Also, Min et al. (2017) found that average daily BWG and FCR were improved by 6 and $4.2 \%$, respectively when broilers were fed on diet containing $0.75 \% \mathrm{Thr}$, comparable to chicks of control diet. However, it was shown that dietary supplementation of Thr up to $1.22 \%$ of recommended level did not significantly changed daily BWG, FI and FCR of Japanese quail reared under tropical conditions (Samuel et al., 2017). Similarly, increasing supplemental L-Thr did not influence weight gain (Dozier et al., 2001; Kidd and Kerr, 1997), as well as FCR values of broilers during the period from 1-21 day of age (Kidd et al., 1999).

The beneficial effect of dietary supplemental Thr in enhancing the productive performance of quail chicks could be due to the effective role of Thr in stimulating the thyroid gland secretions. Wu (2013) and Azzam and El-Gogary (2015) reported that, increasing the dietary content of broilers with the essential amino acid Thr, resulted in increasing production of triiodothyronine $\left(\mathrm{T}_{3}\right)$ and thyroxine $\left(\mathrm{T}_{4}\right)$ hormones due to the presence of Thr receptors in thyroid gland. It was established that $\mathrm{T}_{4}$ hormone is essential for protein and energy metabolism (Johannsen et al., 2012; Mullur et al., 2014) and enhancing the secretion of the IGF-I hormone (Jannini et al., 1995). Moreover, it is needed for protein synthesis and muscular accretion, as well as secretion and function of growth hormone (GH) (Reece, 2015; Hill et al., 2016). Al-Hayani (2017) found an increase in GH level for broiler chickens fed on diets contained Thr at either 600 or 900 $\mathrm{mg} / \mathrm{kg}$. Growth hormone has been reported to stimulate $\mathrm{T}_{3}, \mathrm{~T}_{4}$ and IGF-I secretion, as well its role in protein synthesis and metabolism of amino acid which accelerate protein production (Scanes, 2015). Studies of Kidd and Kerr (1996) and Rao et al. (2011) declared that extra dietary $\mathrm{Thr}$ addition could improve the productive performance of chickens through its participation in nitrogen metabolism process by reducing expenditure and increasing retention of nitrogen.

Data of blood biochemical analyses of Japanese quail chicks as affected by feeding on different protein and Thr levels are presented in Table 3. It is observed that, feeding broiler quail on low protein diets (T2 or $\mathrm{T} 3)$, significantly $\quad(\mathrm{P}<0.01)$ diminished plasma concentration of total protein and globulin when compared with their counterparts of the other treatment groups, in particular those given $150 \% \mathrm{Thr}$ with either $21 \%$ (T6) or $22 \%$ (T4) dietary protein, indicating that chicks fed supplemental Thr had better immune status than those non-supplemented ones.

On the other hand, blood albumin level was not significantly affected by any of the tested diets comparable to the control one. These results are associated with the beneficial effect of Thr in improving quail growth performance. The results of current study are in concomitant with Azzam et al. (2011) who observed an increase in the blood globulin level of laying hens fed on diets contained supplemental L-Thr. They attributed this finding to the increase in the lymphocyte ratios. Also, Min et al. (2017) found that concentrations of plasma total protein and globulin were increased with increasing Thr level from $85 \%$ to $150 \%$ of NRC (1994) recommendations. The affirmative effect of increasing supplemental Thr may be associated with the effective immunoglobulins production, accounting for 7-11\% of total amino acids (Sandberg et al., 2007)

Wang et al. (2006) and Li et al. (2007) revealed that dietary Thr addition enhanced immune response by increasing blood immunoglobulin levels particularly, IgG. In addition, Thr is a principal constituent of plasma $\gamma$-globulin in poultry, rabbits, pig and humans (Kim et al., 2007). Rezaeipour et al. (2012) showed that Thr provision to broiler diets promoted the intestinal digestive 
enzymes secretion, thus increasing the absorption rate of digested food and the available amino acids for synthesis of protein which is consequently reflected in increasing total blood protein level.

Concerning plasma lipid profile, the current findings showed that, chicks fed on diet contained the lowest protein percentage (T3) had significantly the highest triglycerides level, while the lowest levels were obtained for chicks of diets contained low crude protein and supported with either 200 or $150 \%$ of the recommended $\mathrm{Thr}$ requirements. Thus, reduction of triglycerides level was more prominent in T4 and T5.

Converse trend was observed for the plasma concentration of total cholesterol, in which the lowest cholesterol levels $(\mathrm{P}<0.01)$ were measured for chicks given lower dietary protein content without excess $\mathrm{Thr}$ addition (T2 or T3). Moreover, inclusion of extra supplementation of Thr amino acid over the recommended content by 50 or $100 \%$, raised plasma total cholesterol of quail fed on low crude protein diets (T4, T5, T6 and T7).

It is of interest to note that, the blood HDL content displayed nearly similar trend of cholesterol findings. On the other hand, results of plasma LDL concentration exhibited similar trend to that of triglycerides level. These results may reveal that the achieved higher plasma total cholesterol content, is in close association with the effect of supplemental Thr on increasing the plasma HDL content. In partial agreement with our finding, Debnath et al. (2019) reported in blood of broilers fed supplemental Thr that, serum cholesterol and VLDL was significantly $(\mathrm{P}<0.05)$ decreased. But linear increase and decrease were obtained in the blood HDL and LDL cholesterol, respectively. Rezaeipour and Gazani (2014) illustrated that serum VLDL was decreased $(\mathrm{P}<0.05)$ by dietary L-Thr addition. However, Min et al. (2017) showed that serum total cholesterol and triglycerides, were not affected $(\mathrm{P}>0.05)$ by dietary Thr supplementation.
With respect to plasma AST and ALT levels that have been used as indication of liver functions, the current results showed insignificant difference among all experimental groups. This reveals that under the circumstances of the present experiment, broiler quail could withstand the dietary protein restriction up to $2 \%$ lower than the recommended requirements (NRC, 1994) with no adverse effects on their liver functions. Moreover, Thr treatments showed slightly insignificant increase in the plasma ALT activity comparable to control treatment, that is may be referred to the accelerated growth performance and metabolic rate of Thr fed birds. In agreement with this finding, similar results were reported also in Japanese quail chicks by Samuel et al. (2017). Also, Valizade et al. (2016) demonstrated that serum level of AST in broiler chicks was not significantly affected with higher Thr level. These findings indicate that dietary $\mathrm{Thr}$ supplementation had no deleterious effects on hepatic cells of growing quails.

In an earlier study, Miles and Featherston (1974) explained that plasma uric acid in chickens is a precise indicator for determining their requirement of amino acid. Furthermore, Gong et al. (2005) reported that levels of serum uric acid will increase when one or several amino acids are lacking or in excess. Concentration of uric acid and creatinine in quail blood plasma showed that there was a marked increase in both parameters with feeding on diminished dietary protein level whether singly or in combination with extra Thr. In accordance with our results, Min et al. (2017) showed that plasma uric acid content in broilers decreased and then increased as dietary level of Thr increased.

As shown in Table 3, a significant increase was observed in plasma glucose concentration of quail chicks whose diets contained lower crude protein percentages in combination with Thr addition, when compared with chicks of basal diet (control), and those given low protein diets without extra Thr supplementation. Similar results 
Abdel-Fattah et al.

were recently achieved through several authors (Weber et al., 2013; Abdel-Wareth and Esmail, 2014; Debnath et al., 2019) who demonstrated that blood glucose level was significantly increased in broilers with supplemental L- Thr.

Edwards et al., (1997) stated that young chicks catabolize L-Thr producing a number of glucogenic compounds like pyruvate and propionate that are necessary for energy or glucose production. This process might be closely associated with increased blood glucose concentration in the $\mathrm{Thr}$ supplemented groups.

The Effect of supplemental Thr on intestinal histomorphometry and histology is presented in Figures 1 and 2 (a-g), respectively. From the histological investigation, it is obvious that chicks of $\mathrm{T} 2$ and $\mathrm{T} 3$ groups had the lowest villus height (Fig.1) and showed degenerative lining columnar epithelium and goblet cells comparable to that of control and Thr supplemented ones (Fig. 2, b and c). Therefore, quail chicks in T5 group had significantly $(\mathrm{P}<0.05)$ the highest villus height $(\mathrm{VH})$ followed by those of T6 and T7 ones. Besides, supplemental Thr explained a tendency toward increasing goblet cells number with normal lining epithelium which might be related to increase in the absorptive surface area. In accordance with the current histological findings, Nichols and Bertolo (2008) noticed that dietary $\mathrm{Thr}$ supplementation, resulted in greater goblet cell numbers alongside the intestinal villi, consequently higher mucin secretion that protect the intestinal absorptive area from chyme acidity, digestive enzymes activity and pathogenic factors (Horn et al., 2009). The results of Hampson (1986) obtained in piglet showed that; greater villi heights enhanced the activity of enzymes produced from the villi tips, resulting in better digestibility coefficients. On the other hand, Tanure et al. (2015) observed no effect of extra dietary addition of $\mathrm{Thr}$ on $\mathrm{VH}$ in broiler chicks at 14 and 21 day of age.

\section{CONCLUSIONS}

It could be concluded that, supplemental Thr with $150 \%$ of basal requirement was enough to compensate reduction of dietary crude protein below the NRC recommendations in broiler quail. Moreover, Thr supplementation had no adverse effect on kidneys and liver functions and could improve the intestinal status, structures and functions through increasing villi height, goblet cells number and subsequently the absorptive surface area that enhanced the growth performance of supplemented birds. 


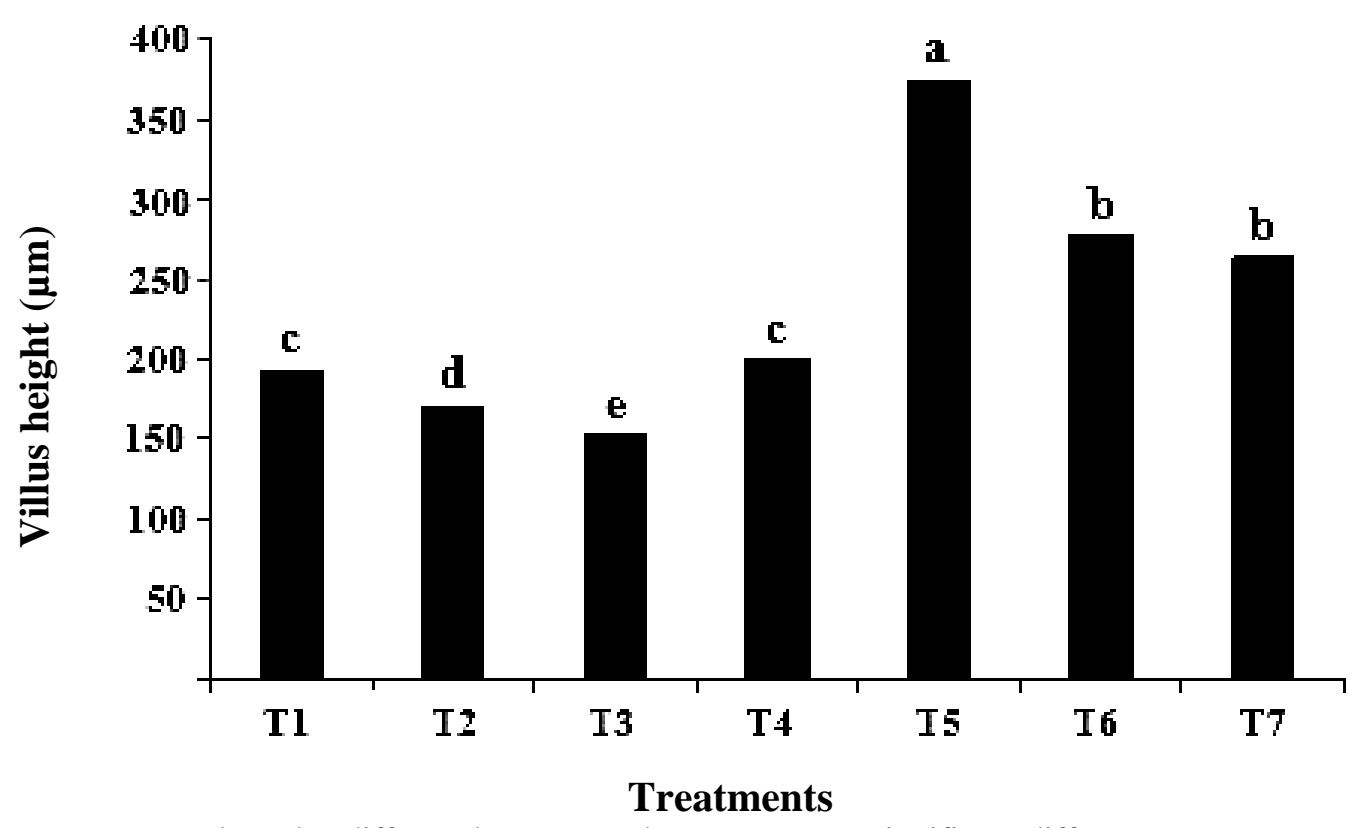

$\mathrm{a}, \mathrm{b}, \mathrm{c}, \mathrm{d}$, e different letters on columns represent significant difference

Fig. (1): Effects of supplemental threonine on intestinal histomorphometry

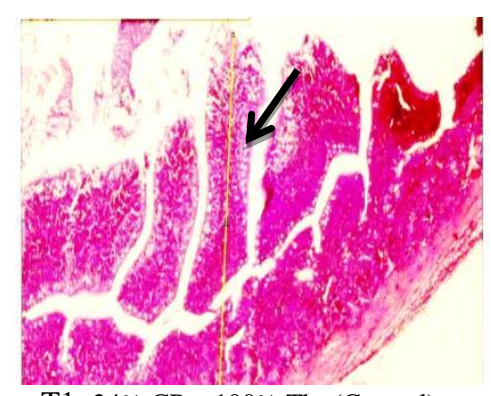

a-T1: $24 \% \mathrm{CP}+100 \% \mathrm{Thr}$ (Control)

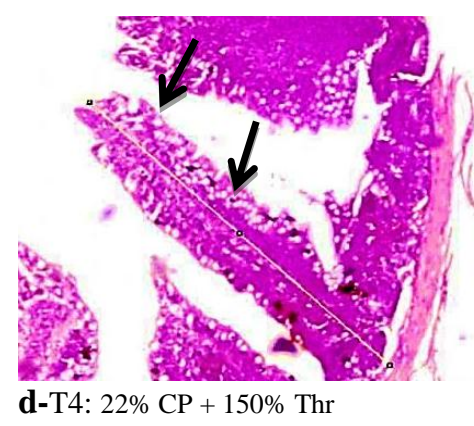

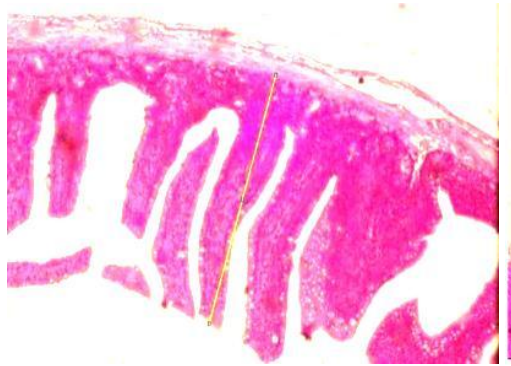

b-T2: $22 \% \mathrm{CP}$

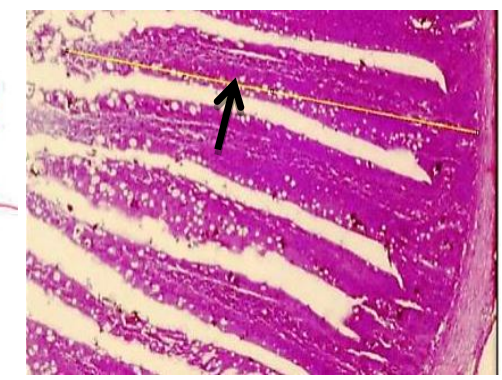

e-T5: $22 \% \mathrm{CP}+200 \% \mathrm{Thr}$

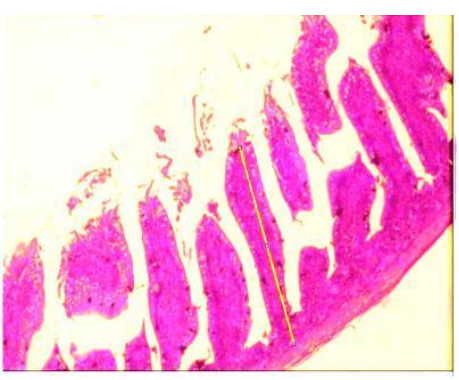

c-T3: $21 \% \mathrm{CP}$

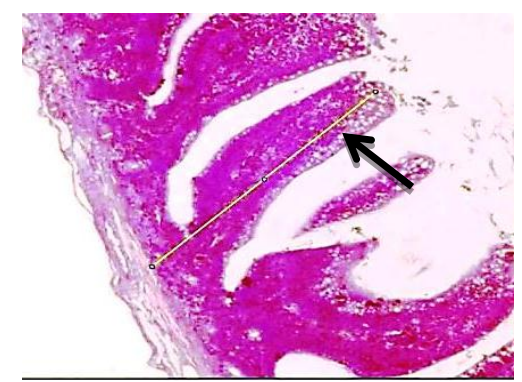

f-T6: $21 \% \mathrm{CP}+150 \% \mathrm{Thr}$ 
Abdel-Fattah et al.
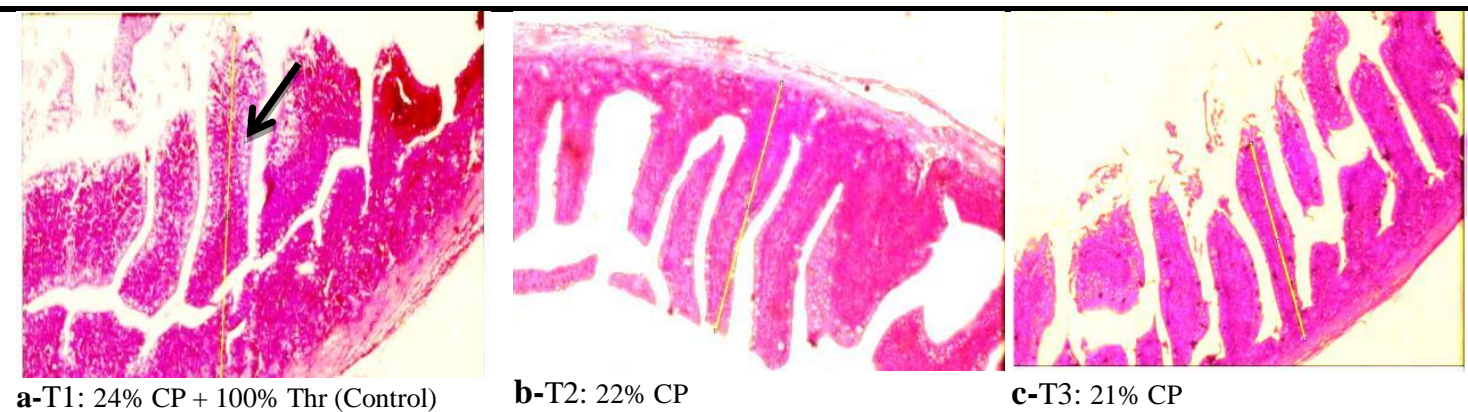

b-T2: $22 \% \mathrm{CP}$

c-T3: $21 \% \mathrm{CP}$

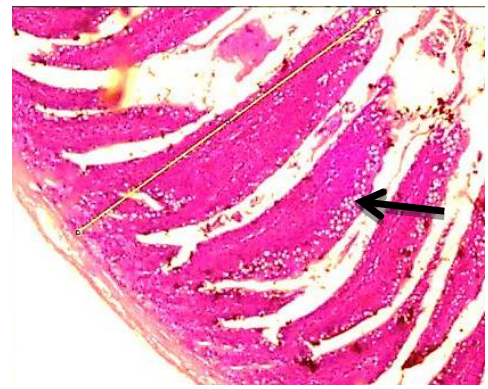

Arrows points to columnar epithelium with goblet cells.

Haematoxylin and eosin stain using 10x magnification powers.

g-T7: $21 \% \mathrm{CP}+200 \% \mathrm{Thr}$

Fig. (2): Effect of supplemental threonine of the intestinal histological status. 
Table (1): Feed ingredients and proximate composition of experimental diets.

\begin{tabular}{|l|c|c|c|c|c|c|c|}
\hline \multirow{2}{*}{ Ingredients } & \multicolumn{7}{|c|}{ Dietary Treatments } \\
\cline { 2 - 8 } & T1 & T2 & T3 & T4 & T5 & T6 & T7 \\
\hline Yellow Corn & 53.79 & 56.97 & 58.97 & 56.96 & 56.86 & 58.49 & 58.35 \\
Soybean meal 44\% & 37.23 & 37.30 & 36.46 & 35.76 & 34.20 & 35.76 & 34.34 \\
Corn Gluten 60\% & 5.00 & 1.30 & 0.05 & 2.40 & 3.50 & 0.60 & 1.60 \\
Vegetable Oil & 0.90 & 1.20 & 1.20 & 1.10 & 1.10 & 1.30 & 1.30 \\
Ca Carbonate & 1.23 & 1.22 & 1.22 & 1.22 & 1.24 & 1.22 & 1.23 \\
Mono Calcium Phosphate & 0.91 & 0.93 & 0.94 & 0.94 & 0.94 & 0.94 & 0.95 \\
Lysine & 0.11 & 0.14 & 0.17 & 0.17 & 0.20 & 0.18 & 0.21 \\
DL-Methionine & 0.10 & 0.15 & 0.17 & 0.14 & 0.13 & 0.17 & 0.16 \\
Threonine & 0.13 & 0.19 & 0.22 & 0.71 & 1.23 & 0.74 & 1.26 \\
Salt (NaCl) & 0.30 & 0.30 & 0.30 & 0.30 & 0.30 & 0.30 & 0.30 \\
Premix\# & 0.30 & 0.30 & 0.30 & 0.30 & 0.30 & 0.30 & 0.30 \\
Total & 100.00 & 100.00 & 100.00 & 100.00 & 100.00 & 100.00 & 100.00 \\
\hline Proximate composition & \multicolumn{7}{|c|}{} \\
\hline Crude Protein \% & 24.05 & 22.06 & 21.09 & 22.06 & 22.05 & 21.08 & 21.06 \\
Metabolizable Energy Kcal/ Kg & 2907 & 2907 & 2909 & 2903 & 2906 & 2907 & 2908 \\
Calcium \% & 0.80 & 0.80 & 0.80 & 0.80 & 0.80 & 0.80 & 0.80 \\
Available Phosphorus \% & 0.30 & 0.30 & 0.30 & 0.30 & 0.30 & 0.30 & 0.30 \\
Lysine \% & 1.30 & 1.30 & 1.30 & 1.30 & 1.30 & 1.30 & 1.30 \\
Methionine \% & 0.50 & 0.50 & 0.50 & 0.50 & 0.50 & 0.50 & 0.50 \\
Cysteine \% & 0.40 & 0.36 & 0.35 & 0.36 & 0.37 & 0.35 & 0.35 \\
Threonine \% & 1.03 & 1.02 & 1.02 & 1.53 & 2.04 & 1.53 & 2.04 \\
Methionine + Cysteine \% & 0.90 & 0.86 & 0.85 & 0.86 & 0.86 & 0.85 & 0.85 \\
C/P Ratio & 121 & 132 & 138 & 132 & 132 & 138 & 138 \\
\hline
\end{tabular}

\#Each $3 \mathrm{Kg}$ of premix contains: Vitamins: A: $12000000 \mathrm{IU}$; Vitamins; $\mathrm{D}_{3} 2000000 \mathrm{IU}$; E: $10000 \mathrm{mg}$; $\mathrm{K}_{3}: 2000 \mathrm{mg} ; \mathrm{B}_{1}: 1000 \mathrm{mg} ; \mathrm{B}_{2}: 5000 \mathrm{mg} ; \mathrm{B}_{6}: 1500 \mathrm{mg} ; \mathrm{B}_{12}: 10 \mathrm{mg}$; Biotin: $50 \mathrm{mg}$; Choline chloride: $250000 \mathrm{mg}$; Pantothenic acid: $10000 \mathrm{mg}$; Nicotinic acid: $30000 \mathrm{mg}$; Folic acid: $1000 \mathrm{mg}$; Minerals: Mn: 60000 mg; Zn: 50000 mg; Fe: 30000 mg; Cu: 10000 mg; I: 1000 mg; Se: 100 mg and Co: 100 $\mathrm{mg}$. 
Abdel-Fattah et al.

Table (2): Effect of dietary treatments on productive performance.

\begin{tabular}{|l|c|c|c|c|c|c|c|c|}
\hline \multicolumn{1}{|c|}{ Items } & \multicolumn{7}{c|}{ Dietary Treatment } \\
\hline & $\mathbf{1}$ & $\mathbf{2}$ & $\mathbf{3}$ & $\mathbf{4}$ & $\mathbf{5}$ & $\mathbf{6}$ & $\mathbf{7}$ & Sig. \\
\hline Initial body weight & 9.01 & 9.02 & 9.03 & 9.03 & 9.01 & 9.02 & 9.01 & \\
(IBW) (one-day of age) & \pm 0.15 & \pm 0.16 & \pm 0.15 & \pm 0.17 & \pm 0.13 & \pm 0.15 & \pm 0.14 & NS \\
Final body weight & $189.23^{\mathrm{a}}$ & $175.01^{\mathrm{ab}}$ & $154.44^{\mathrm{b}}$ & $163.68^{\mathrm{ab}}$ & $163.29^{\mathrm{ab}}$ & $189.31^{\mathrm{a}}$ & $179.51^{\mathrm{ab}}$ & $*$ \\
(FBW) (40 days of age) & \pm 8.56 & \pm 7.09 & \pm 6.28 & \pm 11.81 & \pm 11.73 & \pm 4.40 & \pm 6.16 & \\
Body weight gain & $180.21^{\mathrm{a}}$ & $165.97^{\mathrm{ab}}$ & $145.41^{\mathrm{b}}$ & $154.65^{\mathrm{ab}}$ & $154.30^{\mathrm{ab}}$ & $180.32^{\mathrm{a}}$ & $170.50^{\mathrm{ab}}$ & $*$ \\
(BWG) (0-40 days) & \pm 8.68 & \pm 7.24 & \pm 6.13 & \pm 11.94 & \pm 11.80 & \pm 4.56 & \pm 6.25 & \\
Total feed intake & $665.87^{\mathrm{a}}$ & $606.41^{\mathrm{ab}}$ & $580.46^{\mathrm{b}}$ & $542.65^{\mathrm{c}}$ & $569.10^{\mathrm{bc}}$ & $589.21^{\mathrm{b}}$ & $590.01^{\mathrm{b}}$ & $*$ \\
(TFI) (0-40 days) & \pm 42.73 & \pm 34.13 & \pm 44.05 & \pm 33.60 & \pm 35.69 & \pm 21.53 & \pm 42.53 & \\
Feed conversion ratio (FCR) & $3.71^{\mathrm{b}}$ & $3.67^{\mathrm{b}}$ & $3.97^{\mathrm{a}}$ & $3.51^{\mathrm{bc}}$ & $3.69^{\mathrm{b}}$ & $3.27^{\mathrm{d}}$ & $3.46^{\mathrm{c}}$ & $*$ \\
(0-40 days) & \pm 0.42 & \pm 0.31 & \pm 0.31 & \pm 0.36 & \pm 0.51 & \pm 0.19 & \pm 0.31 & \\
\hline
\end{tabular}

a, b, c, d Means within the same row with different superscripts are significantly different. Sig.=

Significance, $*(\mathrm{P} \leq 0.05)$. NS= Non-Significant.

Table (3): Effect of dietary treatments on blood biochemical parameters.

\begin{tabular}{|c|c|c|c|c|c|c|c|c|}
\hline \multirow[t]{2}{*}{ Items } & \multicolumn{7}{|c|}{ Dietary Treatment } & \multirow[t]{2}{*}{ Sig. } \\
\hline & 1 & 2 & 3 & 4 & 5 & 6 & 7 & \\
\hline \multirow[t]{2}{*}{ Total protein $(\mathrm{g} / \mathrm{dl})$} & $4.54^{\mathrm{bc}}$ & $4.25^{\mathrm{c}}$ & $4.20^{c}$ & $4.90^{\mathrm{ab}}$ & $4.58^{\mathrm{bc}}$ & $5.17^{\mathrm{a}}$ & $4.58^{\mathrm{bc}}$ & \multirow{2}{*}{$* *$} \\
\hline & \pm 0.61 & \pm 0.11 & \pm 0.10 & \pm 0.17 & \pm 0.18 & \pm 0.07 & \pm 0.43 & \\
\hline \multirow[t]{2}{*}{ Albumin (g/dl) } & 2.09 & 1.95 & 2.09 & 2.07 & 1.84 & 2.20 & 2.11 & \multirow{2}{*}{ NS } \\
\hline & \pm 0.04 & \pm 0.06 & \pm 0.11 & \pm 0.07 & \pm 0.07 & \pm 0.09 & \pm 0.11 & \\
\hline \multirow[t]{2}{*}{ Globulin (g/dl) } & $2.45^{\mathrm{bc}}$ & $2.30^{c}$ & $2.11^{\mathrm{d}}$ & $2.83^{\mathrm{a}}$ & $2.74^{\mathrm{ab}}$ & $2.97^{\mathrm{a}}$ & $2.46^{\mathrm{bc}}$ & \multirow{2}{*}{$* *$} \\
\hline & \pm 0.05 & \pm 0.07 & \pm 0.04 & \pm 0.14 & \pm 0.14 & \pm 0.12 & \pm 0.14 & \\
\hline \multirow[t]{2}{*}{ Triglycerides (mg/dl) } & $237.61^{b c}$ & $241.33^{b}$ & $258.77^{\mathrm{a}}$ & $225.43^{d}$ & $228.73^{\mathrm{cd}}$ & $234.39^{c}$ & $231.70^{c}$ & \multirow{2}{*}{$* *$} \\
\hline & \pm 7.70 & \pm 5.23 & \pm 5.23 & \pm 5.07 & \pm 12.46 & \pm 5.29 & \pm 5.32 & \\
\hline \multirow[t]{2}{*}{ Cholesterol (mg/dl) } & $190.33^{\mathrm{cd}}$ & $183.67^{\mathrm{d}}$ & $188.66^{\mathrm{d}}$ & $198.33^{b}$ & $202.33^{\mathrm{ab}}$ & $196.67^{\mathrm{bc}}$ & $209.00^{\mathrm{a}}$ & \\
\hline & \pm 1.21 & \pm 1.76 & $1.76 \pm$ & \pm 3.81 & \pm 4.09 & \pm 1.76 & \pm 1.15 & \\
\hline \multirow[t]{2}{*}{ HDL (mg/dl) } & $35.67^{b}$ & $35.40^{\mathrm{b}}$ & $35.83^{\mathrm{b}}$ & $45.52^{\mathrm{a}}$ & $45.70^{\mathrm{a}}$ & $46.00^{\mathrm{a}}$ & $44.67^{\mathrm{a}}$ & \multirow{2}{*}{$* *$} \\
\hline & \pm 1.07 & \pm 0.56 & \pm 1.25 & \pm 1.27 & \pm 0.98 & \pm 0.72 & \pm 0.90 & \\
\hline \multirow[t]{2}{*}{ LDL (mg/dl) } & $83.43^{b}$ & $94.53^{\mathrm{a}}$ & $93.60^{\mathrm{a}}$ & $80.00^{\mathrm{b}}$ & $72.33^{c}$ & $83.00^{\mathrm{b}}$ & $77.67^{\mathrm{cb}}$ & \\
\hline & \pm 1.60 & \pm 1.36 & \pm 1.18 & \pm 1.53 & \pm 2.03 & \pm 2.65 & \pm 2.60 & \\
\hline \multirow[t]{2}{*}{ ALT (U/L) } & 21.30 & 20.97 & 21.39 & 21.95 & 21.92 & 21.50 & 21.46 & \multirow{2}{*}{ NS } \\
\hline & \pm 0.59 & \pm 1.05 & \pm 0.57 & \pm 0.52 & \pm 1.02 & \pm 1.04 & \pm 0.42 & \\
\hline \multirow[t]{2}{*}{ AST (U/L) } & 82.86 & 85.27 & 82.68 & 79.85 & 81.18 & 75.69 & 77.79 & \multirow{2}{*}{ NS } \\
\hline & \pm 1.66 & \pm 1.07 & \pm 0.99 & \pm 1.90 & \pm 2.51 & \pm 1.99 & \pm 2.70 & \\
\hline \multirow[t]{2}{*}{ Uric acid (mg/dl) } & $5.75^{b}$ & $6.40^{\mathrm{ab}}$ & $6.56^{\mathrm{a}}$ & $5.84^{b}$ & $5.73^{b}$ & $5.91^{\mathrm{b}}$ & $6.59^{a}$ & \multirow{2}{*}{$*$} \\
\hline & \pm 0.21 & \pm 0.33 & \pm 0.07 & \pm 0.18 & \pm 0.15 & \pm 0.20 & \pm 0.17 & \\
\hline \multirow[t]{2}{*}{ Creatinine $(\mathrm{mg} / \mathrm{dl})$} & $0.68^{b}$ & $0.77^{\mathrm{a}}$ & $0.79^{a}$ & $0.69^{b}$ & $0.77^{\mathrm{a}}$ & $0.64^{\mathrm{bc}}$ & $0.71^{\mathrm{ab}}$ & \multirow[t]{2}{*}{$*$} \\
\hline & \pm 0.02 & \pm 0.02 & \pm 0.02 & \pm 0.03 & \pm 0.02 & \pm 0.02 & \pm 0.03 & \\
\hline \multirow[t]{2}{*}{ Glucose (mg/dl) } & $240.67^{\text {bc }}$ & $239.33^{\mathrm{cd}}$ & $231.33^{\mathrm{d}}$ & $246.33^{b c}$ & $249.00^{\mathrm{ab}}$ & $256.67^{\mathrm{a}}$ & $255.33^{\mathrm{a}}$ & \multirow[t]{2}{*}{$* *$} \\
\hline & \pm 3.38 & \pm 3.52 & \pm 2.03 & \pm 2.72 & \pm 2.89 & \pm 2.33 & \pm 1.28 & \\
\hline
\end{tabular}

${ }^{a}, b, c, d$ Means within the same row with different superscripts are significantly different. Sig. $=$ Significance ** $(\mathrm{P} \leq 0.01),{ }^{*}(\mathrm{P} \leq 0.05) . \mathrm{NS}=$ Non-Significant. 


\section{REFERENCES}

Abbasi, M.A., A.H. Mahdavi, A.H. Samie and R. Jahanian, 2014. Effects of different levels of dietary crude protein and threonine on performance, humoral immune responses and intestinal morphology of broiler chicks. Braz. J. Poult. Sci., 16: 35-44.

Abdel-Wareth, A.A.A., and Z.S.H. Esmail 2014. Some productive egg quality and serum metabolic profile responses due to L-threonine supplementation to laying hen diets. Asian J. Poult. Sci., 8: 75-81.

Aksu, T., M.I. Aksu, M.A. Yoruk and M. Karaoglu 2011. Effects of organicallycomplexed minerals on meat quality in chickens. Br. Poult. Sci., 52: 558-563.

Al-Hayani, W.K.A. 2017.Effect of Threonine Supplementation on Broiler Chicken Productivity Traits. I. J. Poult. Sci., 16: 160-168.

Ao, T., J.L. Pierce, R. Power, A.J. Pescatore, A.H. Cantor, K.A. Dawson and M.J. Ford 2009. Effects of feeding different forms of zinc and copper on the performance and tissue mineral content of chicks. Poult. Sci., 88: 2171-2175.

AOAC 2010. Official Methods of Analysis of Association of Official Analytical Chemists. 18th Ed, Washington, DC.

Ayasan, T., 2004.Investigation of threonine requirements of broilers. $\mathrm{PhD}$ Thesis in Animal Science, Faculty of Agriculture, Cukurova University, Adana.

Azzam, M.M.M. and M.R. El-Gogary 2015. Effects of dietary threonine levels and stocking density on the performance, metabolic status and immunity of broiler Chickens. Asian J. Anim. Vet. Adv., 10: 215-225.

Azzam, M.M.M., X.T. Zou, X.Y. Dong, P. Xie 2011. Effect of supplemental Lthreonine on mucin 2 gene expression and intestine mucosal immune and digestive enzymes activities of laying hens in environments with high temperature and humidity. Poult. Sci., 90: 2251-2256.
Bancroft, J.D. and A. Stevens 1990. Theory and Practice of Histological Techniques. 3rd Ed., Churchill Livingstone, New York, USA.

Britanico, E.B., F.E. Merca, A.A. Angeles, S.P. Acda and E.S. Luis 2012. Effects of supplementing diets with amino acid chelates of copper, zinc, manganese and iron on the performance of broilers. Philipp. J. Vet. Anim. Sci., 38: 1-10.

Caraway, W.T. 1955. Determination of uric acid in serum by a carbonate method. Am. J. Clin. Pathol., 25: 840-845.

Chen, Y.P., Y.F. Cheng, X.H. Li, W.L. Yang, C. Wen, S. Zhuang and Y.M. Zhou 2017. Effects of threonine supplementation on the growth performance, immunity, oxidative status, intestinal integrity, and barrier function of broilers at the early age. Poult. Sci., 96: 405-413.

Debnath, B.C., P. Biswas and B. Roy 2019. The effects of supplemental threonine on performance, carcass characteristics, immune response and gut health of broilers in subtropics during pre- starter and starter period. J. Anim. Physiol. Anim. Nutr., 103: 29-40.

Doumas, B.T., W.A. Watson and H.G. Biggs 1971. Albumin standards and the measurement of serum albumin with bromcresol green. Clin. Chem. Acta., 31: 87-96.

Dozier, W.A. III, E.T. Moran Jr. and M.T. Kidd 2001. Comparisons of male and female broiler responses to dietary threonine from 42 to 56 days of age. J. Appl. Poult. Res., 10: 53-59.

Duncan, D.B. 1955. Multiple range and Multiple F tests. Biometrics, 11: 1-42.

Duval, D., C. Demangel, K. Munier-Jolain, S. Miossec, I. Geahel 1991. Factors controlling cell proliferation and antibody production in mouse hybridoma cells: I. influence of the amino acid supply. Biotechnol. Bioeng., 38: 561-570.

Edwards, H.M. III, D.H. Baker, S.R. Fernandez, and C.M. Parsons 1997. Maintenance threonine requirement and 
Abdel-Fattah et al.

efficiency of its use for accretion of whole-body threonine and protein in young chicks. Br. J. Nutr., 78: 111-119.

El-Senousey, H.K., B. Chen, J.Y. Wang, A.M. Atta, F.R. Mohamed and Q.H. Nie 2018. Effects of dietary vitamin $C$, vitamin $\mathrm{E}$, and alpha-lipoic acid supplementation on the antioxidant defense system and immune-related gene expression in broilers exposed to oxidative stress by dexamethasone. Poult. Sci., 97: 30-38.

Estalkhzir, F.M., S. Khojasteh and M. Jafari 2013. The effect of different levels of threonine on performance and carcass characteristics of broiler chickens. J. Nov. Appl. Sci., 2: 382-386.

FAO 2013. Poultry Development Review. Rome, Italy, Available at: http://www.fao.org/docrep/019/i3531e/i3 531e.pdf.

Fathi. M., M. Haydari and T. Tanha 2016. Effects of zinc oxide nanoparticles on antioxidant status, serum enzymes activities, biochemical parameters and performance in broiler chickens. J. Livest. Sci. Technol., 4: 7-13.

Gong, L.M., C.H. Lai, S.Y. Qiao, D. Li, Y.X. Ma and Y.L. Liu 2005. Growth performance, carcass characteristics, nutrient digestibility and serum biochemical parameters of broilers fed low-protein diets supplemented with various ratios of threonine to lysine. Asian-Austral. J. Anim. Sci., 18: 11641170.

Gornall, A.G., C.J. Bardawill and M.M. David 1949. Determination of serum proteins by means of Biuret reaction. J. Biol. Chem., 177: 751-766.

Hampson, D.J. 1986. Alterations in piglet small intestinal structure at weaning. Res. Vet. Sci., 40: 32-40.

Hill, R.W., G.A. Wyse and M. Anderson 2016. Animal Physiology. 4th Ed., Sinauer Associates, Inc., Publishers, USA.

Horn, N.L., S.S. Donkin, T.J. Applegate and O. Adeola 2009. Intestinal mucin dynamics: response of broiler chicks and White Pekin ducklings to dietary threonine. Poult. Sci., 88: 1906-1914.

Herrmann, W., C. Schütz, W. Reuter 1983. Determination of HDL-cholesterol. Z. Gesamte Inn. Med., 38: 17-22.

Jannini, E.A., S. Ulisse and M. D'Armiento 1995. Thyroid hormone and male gonadal function. Endocr. Rev., 16: 443-459.

Johannsen, D.L., J.E. Galgani, N.M. Johannsen, Z. Zhang, J.D. Covington and E. Ravussin 2012. Effect of shortterm thyroxine administration on energy metabolism and mitochondrial efficiency in humans. PLoS One, Vol. 7.

Khan, A.R., H. Nawaz and I. Zahoor 2006. Effect of different levels of digestible threonine on growth performance of broiler chicks. J. Anim. Pl. Sci., 16: 8-11.

Kidd, M.T. and B.J. Kerr 1996. L-threonine for poultry: A review. J. Appl. Poult. Res., 5: 358-367.

Kidd, M.T. and B.J. Kerr 1997. Threonine responses in commercial broilers at 30 to 42 days. J. Appl. Poult. Res., 6: 362-367.

Kidd, M.T., S.P. Lerner, J.P. Allard, S.K. Rao and J.T. Halley 1999. Threonine needs of finishing broilers: growth, carcass and economic responses. J. Appl. Poult. Res., 8: 160-169.

Kim, S.W., R.D. Mateo, Y.L. Yin and G. Wu 2007. Functional amino acids and fatty acids for enhancing production performance of sows and piglets. AsianAust. J. Anim. Sci., 20, 295-306.

Li, P., Y.L. Yin, D. Li, S.W. Kim and G. Wu 2007. Amino acids and immune function. Br. J. Nutr., 98: 237-252.

Li, D.F., C.T. Xiao, S.Y. Qiao, J.H. Zhang, E.W. Johnson, and P.A. Thacker 1999. Effects of dietary threonine on performance, plasma parameters and immune function of growing pigs. Anim. Feed Sci. Technol., 78: 179-188.

Miles, R.D. and W.R. Featherston 1974. Uric acid excretion as an indicator of the amino acid requirement of chicks. Proc. Soc. Exp. Biol. Med. 145: 686-689. 
threonine; quail; protein; performance; blood; histology

Min, Y.N., S.G. Liu, Z.X. Qu, G.H. Meng and Y.P. Gao 2017. Effects of dietary threonine levels on growth performance, serum biochemical indexes, antioxidant capacities, and gut morphology in broiler chickens, Poult. Sci., 96: 5: 1290-1297.

Mullur, R., Y.Y. Liu and G.A. Brent 2014. Thyroid hormone regulation of metabolism. Physiol. Rev., 94: 355-382.

Nichols, N.L. and R.F. Bertolo 2008. Luminal threonine concentration acutely affects intestinal mucosal protein and mucin synthesis in piglets. J. Nutr., 138: $1298-1303$.

NRC 1994. National Research Council. Nutrient Requirements of Poultry 9th Rev. Ed. Composition of poultry feedstuffs. National Academy Press, Washington, DC, USA. p.p. 61-75.

Okada, M. and R. Ishida 2001. Direct measurement of low-density-lipoprotein cholesterol is more effective than total cholesterol for the purpose of lipoprotein screening. Prev. Med., 32: 224-229.

Olukomaiya, O., C. Fernando, R. Mereddy, X. Li, and Y. Sultanbawa 2019. Solid-state fermented plant protein sources in the diets of broiler chickens: A review. Anim. Nutr., 5: 319-330.

Rao, S.V.R., M.V.L.N. Raju, A.K. Panda, N.S. Poonam, O.K. Moorthy, T. Srilatha and G.S. Sunder 2011. Performance, carcass variables and immune responses in commercial broiler chicks fed graded concentrations of threonine in diet containing sub-optimal levels of protein. Anim. Feed Sci. Technol., 169: 218-223.

Reece, W.O. 2015. Dukes' Physiology of Domestic Animals. Wiley Blackwell, A John Wiley and Sons, Ltd., USA.

Reitman, S. and S. Frankel 1957. A colorimetric method for the determination of serum glutamic oxalacetic and glutamic pyruvic transaminases. Am. J. Clin. Pathol., 28: 56-63.

Rezaeipour, V. and S. Gazani 2014. Effects of feed form and feed particle size with dietary L- threonine supplementation on performance, carcass characteristics and blood biochemical parameters of broiler chickens. J. Anim. Sci. Technol., 56: 20.

Rezaeipour, V., H. Fononi, and M. Irani 2012. The effects of dietary L-threonine and Saccharomyces cerevisiae on performance, intestinal morphology and immune response of broiler chickens. S. Afr. J. Anim. Sci., 42: 266-273.

Rezaeipour, V., A. Valizadeh, R. Abdullahpour and A.R. Sadeghi 2015. Effects of dietary threonine and a multi strains probiotic (Primalac) supplementation on growth performance, blood metabolites and carcass characteristics in Japanese quails. Poult. Sci. J., 3: 135-141.

Richmond, W. 1973. Preparation and properties of a cholesterol oxidase from Nocardia sp. and its application to the enzymatic assay of total cholesterol in serum. Clin. Chem., 19: 1350-1356.

Samuel, I., G.S. Bawa, O.M. Daudu, O.J. Makinde, E.A. Ibe and A.R. Akintunde 2017. Determination of optimum threonine requirements of Japanese quail (Coturnix coturnix japonica) chicks reared under tropical environment. Trop. Subtrop. Agroecosyst., 20: 419-427.

Sandberg, F.B., G.C. Emmans and I. Kyriazakis 2007. The effects of pathogen challenges on the performance of naïve and immune animals: the problem of prediction. Animal, 1: 67-86.

SAS 2004. SAS/STAT ${ }^{\circledR} 9.1$ User's Guide. Cary, NC: SAS Institute Inc.

Scanes, C.G.2005. Pituitary gland. In: Sturkie's avian physiology. 6th Ed. Ch. 23. Edited by Colin G. Scanes. Elsevier Inc., London.

Schaart, M.W., H. Schierbeck, S.R. van der Schoor, B. Stoll, D.G. Burrin, P.J. Reeds and J.B. van Goudoever. 2005. Threonine utilization is high in the intestine of piglets. J. Nutr., 135: 765-770.

Tanure, C.B.G.S., J.S. Santos, E.M. Oliveira, M. Laboissiere, A.M.C. Racanicci, C.M. McManus, M.B. Café and J.H. Stringhini 2015. Digestible 
threonine levels in the starter diet of broilers derived from breeders of different ages. Braz. J. Poult. Sci., 15161635.

Trinder, P. 1969. Determination of glucose in blood using glucose oxidase with an alternative oxygen acceptor. Ann. Clin. Biochem., 6: 24-27.

Valizade, M.R., A.A. Sadeghi, M. Chamani, P. Shawrang, and N. Kashan 2016. The effects of increase in threonine to lysine ratio on performance, blood parameters and humoral immune responses of male broiler chickens challenged with salmonella. Kafkas. Univ. Vet. Fak. Derg. 22: 165-172.

Van der Schoor, S.R., P.J. Reeds, B. Stoll, J.F. Henry, J.R. Rosenberger, D.G. Burrin, and J.B. Van-Goudoever 2002. The high metabolic cost of a functional gut. Gastroenterology, 123: 1931-1940.

Vargas-Sánchez, R.D., F.J. Ibarra-Arias, B.D.M. Torres-Martínez, A. SánchezEscalante and G.R. Torrescano-
Urrutia 2019. Use of natural ingredients in Japanese quail diet and their effect on carcass and meat quality - A review. Asian Aust. J. Anim. Sci., 32: 1641-1656.

Wang. X., S.Y. Qiao, M. Liu and Y.X. Ma 2006. Effects of graded levels of true ileal digestible threonine on performance, serum parameters and immune function of 10-25 kg pigs. Anim. Feed Sci. Technol., 129: 264-278.

Watson, D. 1960. A simple method for the determination of serum cholesterol. Clin. Chem. Act., 5: 637-643.

Weber, G.M., V. Machander, J. Schierle, R. Aureli, F. Roos, and A.M. Perez- Vendrell 2013. Tolerance of poultry against an overdose of canthaxanthin as measured by performance, different blood variables and post- mortem evaluation. Anim. Feed Sci. Technol., 186, 91-100.

Wu, G., 2013. Amino Acids, Biochemistry and Nutrition. CRC Press, Taylor and Francis Group, New York. 


$$
\text { الملخص العربي }
$$

\section{إضافة الثريونين لاعم الأداء الإنتاجي والحالة الفسيولوجية للسمان الياباني المغذى على علائق محددة البروتين}

\section{سيد أحمد عبدالفتاح1، أحمد أحمد خطاب² ومروان عبدالعزيز محمود عبدالعزيز1}

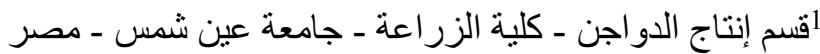

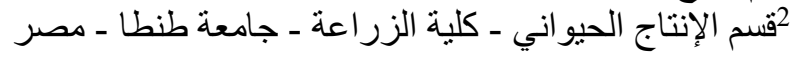

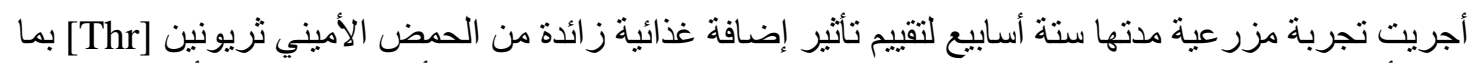

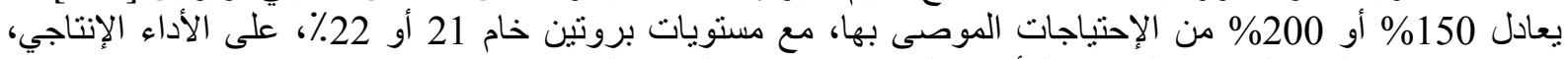

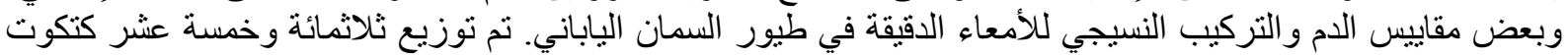

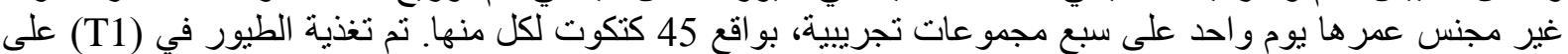

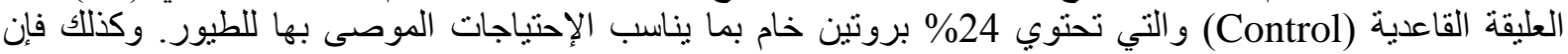

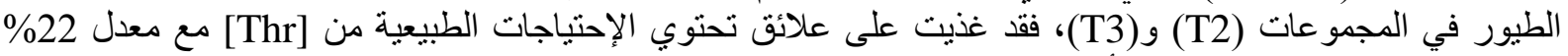

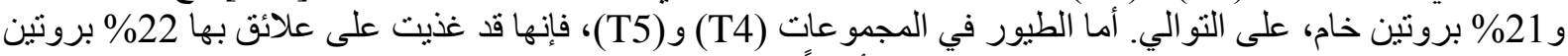

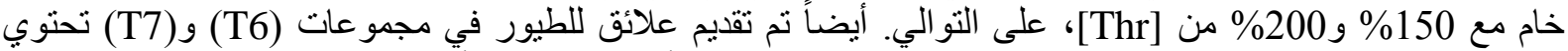

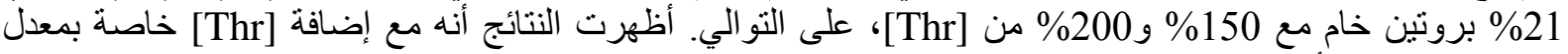

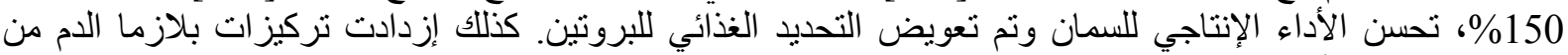

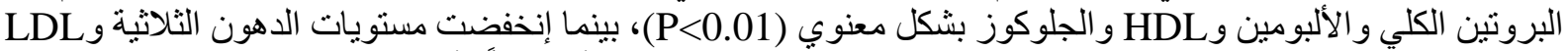

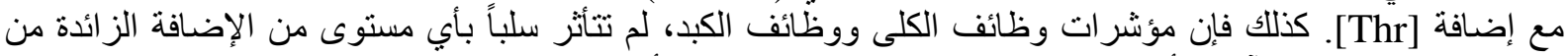

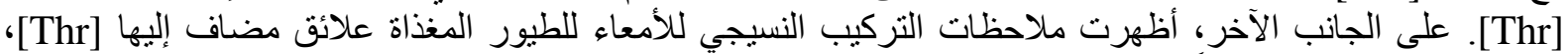

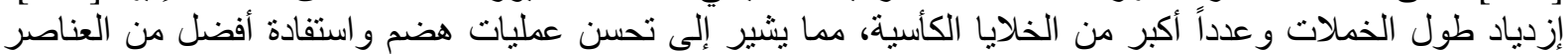

